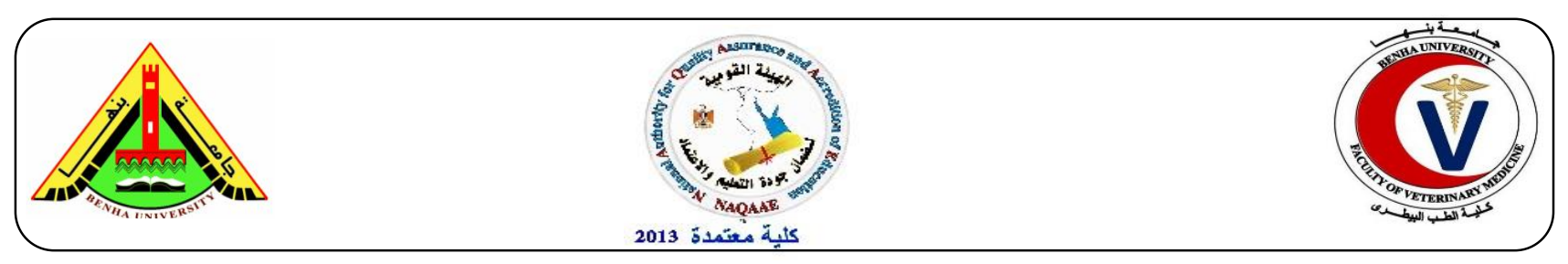

\title{
Effect of Egg White Hydrolysates on Shelf Life of Soft Cheese
}

\author{
Eman A. Nafei, Hend A. Elbarbary, Adham M. Abdou and Hamdi A. Mohamed \\ Department of Food Hygiene, Faculty of Veterinary Medicine, Benha University, Egypt.
}

\section{A B S T R A C T}

The aim of work is to evaluate antibacterial activities of egg white hydrolysates against Escherichia coli, Staphylococcus aureus and Bacillus subtilus. Also, the effect of the highest antibacterial hydrolysate on shelf life of soft cheese was evaluated. The Egg white hydrolysis was conducted in 1 $\mathrm{mol} / \mathrm{l} \mathrm{HCl}$ solution ( $\mathrm{pH} 1.5,2,2.5,3,3.5,4,4.5)$ at temperature of $37^{\circ} \mathrm{C}$ for 48 hours using pepsin enzyme ( $2 \%$ enzyme/substrate $(\mathrm{E} / \mathrm{S})$ ratio). Results revealed that raw egg hydrolysate $(\mathrm{REWH})$ hydrolyzed at $\mathrm{pH} 1.5$ after 12 hours was the most potent antibacterial hydrolysate. This hydrolysate extended the shelf life of soft cheese to 28 days. In addition, this hydrolysate showed a significant inhibitory effect on total bacterial count and yeast \& mold count. Escherichia coli was the most sensitive organism to this hydrolysate. Accordingly, REWH obtained at $\mathrm{pH} 1.5$ is considered as the most efficient natural preservative to be applied in food system.

Keywords: Egg white hydrolysis, antimicrobial activity, soft cheese.

(http://www.bvmj.bu.edu.eg) $\quad$ (BVMJ-35(2): 134-141, 2018)

\section{INTRODUCTION}

Egg White is a viscous biological fluid that contain many biologically active proteins including ovalbumin $(54 \%)$, lysozyme $(3.5 \%)$ and ovotransferrin $(12 \%)$ are responsible for the most potent antimicrobial activity of egg white (Miguel et al., 2005). The protein hydrolysis is a chemical reaction in which enzyme bind to peptide bonds in presence of water for production of bioactive peptides and free amino acids (Adler-Nissen, 1993). During the enzymatic hydrolysis, the ability of enzymes to cut peptide bonds of substrates depend on the availability of hydrophobic regions within the peptide chain (Archer et al., 1973). The adjustment of $\mathrm{pH}$ and temperature at the end of enzymatic hydrolysis is required for enzyme inactivation (Lahi and Braun,
1994) and not affect on sensory properties of protein hydrolysates (Pedersen, 1994). Egg white hydrolysates (EWHs) have peptides with improved functional and biological activities including ACE inhibitory, antioxidant, antibacterial and antihypertensive activities (Mine and Kovacs-Nolan, 2006). Antimicrobial egg white hydrolysates contain both cationic or amphipathic and hydrophobic peptides which can exert its antimicrobial activity either through direct lysis of bacterial cell membrane (Wong and $\mathrm{Ng}, 2005$ ) or through trans-membrane pore-forming mechanism (Van dijk et al., 2008). The wide application of protein hydrolysates in food industry is attributed to its higher quality, higher productivity, non-toxicity, heat stability 
and with a higher solubility at wide range of pH (Tian, 2001).

There are many parameters that affect on rate of spoilage of soft cheeses include water activity, $\mathrm{pH}$, salt to moisture ratio (Dermiki et al., 2008), and consequently higher microbial spoilage that occur during the manufacture, handling and storage of the cheese (Sadek et al., 2009).

Few studies had been reported on the antibacterial property of egg white. Therefore, the aim of the present work was to evaluate the effect of the highest antibacterial hydrolysate on the quality and shelf life of soft cheese.

\section{Materials and methods}

\subsection{Materials}

Pepsin (EC 3.4.23.1, $3000 \mathrm{U} / \mathrm{mg}$ from porcine gastric mucosa) was purchased from Sigma Aldrich Chemical Co. Crude egg white was separated from fresh chicken eggs bought from El-Eslah poultry farm, Quisna, ELMenofia Governorate, Egypt. Cultures of Bacillus subtilis, E. coli and Staph. aureus strains were obtained from Department of Microbiology, Faculty of Veterinary Medicine, Benha University, Egypt.

\subsection{Hydrolysis of egg white}

The hydrolysis of egg white suspension by pepsin enzyme was applied by the method of Garces-Rimon et al (2016). Egg white was dissolved in distilled water at ratio of $1: 1(\mathrm{w} / \mathrm{w})$. The $\mathrm{pH}$ of egg white suspension was adjusted to $\mathrm{pH} 1.5,2,2.5,3,3.5,4,4.5$ with 1.0 $\mathrm{mol} / \mathrm{l} \mathrm{HCl}$ aqueous solution. The reaction was initiated by the addition of pepsin enzyme to obtain enzyme to substrate ratio of $2 \%(\mathrm{w} / \mathrm{w})$, and $\mathrm{pH}$ was kept stable by adding $1 \mathrm{~mol} / \mathrm{l} \mathrm{HCl}$ solution using automatic potentiometric tirator. The hydrolysates were incubated at $37^{\circ} \mathrm{C}$ for $48 \mathrm{hrs}$ in a shaking water bath. The samples were adjusted to $\mathrm{pH} 7.0$ with $1 \mathrm{M}$ $\mathrm{NaOH}$ to inactivate the enzyme. The obtained hydrolysates evaluated for antibacterial activity. In addition, egg white suspension without the addition of enzyme was kept as a control.

\subsection{Determination of protein concentration}

Total protein content $(\mathrm{N} \times$ 6.25) in insoluble substrate and hydrolysates was determined with Kjeldahl method (Crooke and Simpson, 1971).

2.4. Determination of antibacterial activity of EWHs

Antibacterial activities of EWHs were determinated by agar well diffusion assay (Aničić et al., 2005). The strains Bacillus subtilis, Staph. aureus and E. coli were grown in tryptic soy broth (TSB) at $37^{\circ} \mathrm{C}$ for $18 \mathrm{~h}$. These strains were activated and adjusted to about $4 \quad \log _{10} \quad \mathrm{cfu} / \mathrm{mL}$. Each bacterial suspension was spread over the surface of tryptic soy agar (TSA). Then, the sterile of 1$\mathrm{cm}$-diameter wells were loaded with $200 \mu \mathrm{l}$ of hydrolysates. The plates were incubated at $37^{\circ} \mathrm{C} / 24$ hours under aerobic conditions and examined for clear circular inhibition zone.

\subsection{Preparation of soft cheese}

A total of ten liter of fresh raw cow's milk were obtained from the herd of Faculty of Veterinary Medicine, Benha University. Soft cheese was manufactured according to the method described by Deshmukh et al (2009) as follows: The bulk volume of milk was divided into 2 equal portions as follows: The first portion was kept uncoated and served as control and the second portion was inoculated with the most potent antibacterial EWH. After coagulation, the curd of each batch was left to drain. Then, the cheeses were then aseptically cut and stored in the refrigerator temperature at $4^{\circ} \mathrm{C}$. The cheese samples were examined microbiologically at zero time till signs of spoilage were detected. The experiment was repeated 3 times and the average results for each treatment were recorded.

2.6. Microbiological examination of soft cheese coated with EWH 
Cheese samples were examined for total bacterial count (TBC), total coliform and $E$. coli count and mould \& yeasts according to Mucchetti et al (2008).

\subsection{Determination of antibacterial activity of} EWH against some pathogens in soft cheese

Cheese was manufactured as previously described according to Deshmukh et al (2009). The strains of E. coli, Bacillus subtilus and staph. aureus used as indicator organisms. They were activated as previously described till obtain concentration of (3-4) $\log _{10} \mathrm{cfu} / \mathrm{gm}$ then inoculated into soft cheese samples. Bacteriological analysis for counting these pathogens was carried out and examined at zero time and during storage period for 28 days at $4^{\circ} \mathrm{C} \pm 2$.

\subsection{Statistical analysis}

Differences among means of three trials were tested for significance $(\mathrm{P}<0.05)$ as described by Hill and Lewicki (2007). Statistical analysis of the data was carried out employing analysis of variance (ANOVA).

\section{RESULTS}

The results showed that there are variable degrees of antibacterial activity were also observed for other hydrolysates against tested strains (Table, 1). The raw hydrolysate obtained at $\mathrm{pH} 1.5$ after $12 \mathrm{hrs}$ showed the highest inhibition zone against Bacillus subtillus (inhibition zone diameter $6.38 \mathrm{~mm}$ ). The protein concentrations of these antibacterial hydrolysates ranged from $(3.53 \%$ to $7.82 \%$ ) in REWH and CPEWH, respectively (Data not shown).

Table (2) revealed average of total bacterial counts (TBC) of cheese samples. Total bacterial counts (TBC) increased gradually in the control samples from the day of production at $(5.48 \pm 0.28) \log _{10} \mathrm{cfu} / \mathrm{gm}$ until reached its maximum level at the end of storage. The total bacterial counts in EWHs coated cheese samples were lower than control samples beginning from $7^{\text {th }}$ day at $(5.28 \pm 0.44)$ $\log _{10} \mathrm{cfu} / \mathrm{gm}$ till $21^{\text {st }}$ day of refrigerated storage $(4.15 \pm 0.49) \log _{10} \mathrm{cfu} / \mathrm{gm}$ then gradually increased until spoiled after 28 days of refrigerated storage. Neither coliform nor E. coli could be detected in fresh and during storage period in all the examined cheese samples. These results were in agreement with EOS (2000). Yeasts and moulds were not detected in any of the samples on the $1^{\text {st }}$ day of the storage. During storage period, the yeast and mould in control sample increased gradually from $(6.10 \pm 0.18) \log _{10} \mathrm{cfu} / \mathrm{gm}$ at $7^{\text {th }}$ day and reached its maximum level at $14^{\text {th }}$ day of storage period $(7.80 \pm 0.22) \log _{10} \mathrm{cfu} / \mathrm{gm}$. However, in coated cheese sample, the yeast and mould count decreased gradually beginning from $(5.61 \pm 0.11) \log _{10} \mathrm{cfu} / \mathrm{gm}$ at $7^{\text {th }}$ day to $(3.41 \pm 0.23) \log _{10} \mathrm{cfu} / \mathrm{gm}$ at $14^{\text {th }}$ day until fungal growth was not detected at $21^{\text {th }}$ day of refrigerated storage then fungal growth increased until spoilage at $29^{\text {th }}$ day (Table, 2).

Table (3) revealed that there was no a significant inhibition of growth of staph. aureus in coated cheese samples at which the bacterial count increased from day of production $(3.59 \pm 0.018) \log _{10} \mathrm{cfu} / \mathrm{gm}$ till reached to $(6.25 \pm 0.346) \log _{10} \mathrm{cfu} / \mathrm{gm}$ at 7 th day of refrigerated storage. There was a significant difference between the count of $E$. coli in control samples and samples coated with $3.53 \%$ EWHs $(\mathrm{P} \leq 0.05)$ as shown in (Table,3) at which the high count of E. coli in EWHs coated sample was gradually decreased from the 1st day of production $(4.38 \pm 0.032)$ $\log _{10} \mathrm{cfu} / \mathrm{gm}$ till reached to $(1.19 \pm 0.191) \log _{10}$ $\mathrm{cfu} / \mathrm{gm}$ at end of refrigerated storage compared with bacterial count in control sample which was $(2.09 \pm 0.026) \log _{10} \mathrm{cfu} / \mathrm{gm}$. The growth and survival pattern of Bacillus subtilis in cheese is presented in (Table, 3). EWHs showed a significant inhibitory effect $(\mathrm{P} \leq$ 0.05 ) against beginning from 3rd day at (5.01 
$\pm 0.233) \log _{10} \mathrm{cfu} / \mathrm{gm}$ until (4.52 \pm 0.057$) \log _{10}$ $\mathrm{cfu} / \mathrm{gm}$ at 5 th day of refrigerated storage.

\section{Conclusion}

The current study had been concluded that use of natural preservatives can prolong the shelf life of dairy product Consequently, 3.53\% REWHs prepared at $\mathrm{pH}, 1.5$ for $12 \mathrm{hrs}$ were more effective in the inhibition of some food

Table 1: Inhibition zones of antibacterial egg white hydrolysates (EWHs) against some pathogenic microorganisms.

\begin{tabular}{|c|c|c|c|}
\hline $\begin{array}{l}\text { Antibacterial egg white } \\
\text { hydrolysates }\end{array}$ & $S$ & $\mathrm{E}$ & B \\
\hline $\begin{array}{l}\text { REWHs at } \mathrm{pH} 1.5 \text { for } \\
12 \mathrm{hrs}\end{array}$ & $5.00 \pm 0.50 *$ & $5.25 \pm 0.15^{*}$ & $6.38 \pm 2.29 *$ \\
\hline $\begin{array}{l}\text { EWHs at pH3.5 for } \\
12 \mathrm{hrs}\end{array}$ & ND & ND & $5.32 \pm 1.77 *$ \\
\hline $\begin{array}{l}\text { HPEWHs at } \mathrm{pH} 2.5 \text { for } \\
1 \mathrm{hr}\end{array}$ & ND & $4.92 \pm 0.63^{*}$ & ND \\
\hline $\begin{array}{l}\text { HPEWH at } \mathrm{pH} 3.5 \text { for } \\
24 \mathrm{hrs}\end{array}$ & $3.25 \pm 0.66^{*}$ & $3.33 \pm 0.38^{*}$ & $5.08 \pm 1.88 *$ \\
\hline $\begin{array}{l}\mathrm{CPEWH} \text { at } \mathrm{pH} 4.5 \text { for } \\
8 \mathrm{hrs}\end{array}$ & $2.45 \pm 0.14^{*}$ & ND & $4.58 \pm 2.92 *$ \\
\hline
\end{tabular}

S: S.aureus

E: E. coli

B: Bacillus.subtilus borne pathogens including E. coli, Staph.aureus and Bacillus.subtilus. The addition of these hydrolysates in soft cheese caused a significant slowdown in microbial growth during refrigerated storage as well as extended the shelf life up to 28 days.

(N.D): No Inhibition Detected, *the results shown were the mean \pm standard error (SE)

Table 2: Microbiological profile of soft cheese coated with 3.53\% EWHs during refrigerated storage.

\begin{tabular}{lccc}
\hline Microorganisms & $\begin{array}{c}\text { Storage time } \\
\text { (Days) }\end{array}$ & $\begin{array}{c}\text { Control Sample } \\
\left(\log _{10} \mathrm{cfu} / \mathrm{g}\right)\end{array}$ & Coated Sample \\
\hline Total bacterial counts & 1 & $5.48 \pm 0.28^{\mathrm{aA}}$ & $5.47 \pm 0.30^{\mathrm{aA}}$ \\
& 4 & $6.58 \pm 0.85^{\mathrm{aB}}$ & $5.28 \pm 0.44^{\mathrm{aB}}$ \\
& 14 & $7.01 \pm 0.18^{\mathrm{aC}}$ & $4.49 \pm 0.94^{\mathrm{bE}}$ \\
& 21 & $\mathrm{~S}$ & $4.15 \pm 0.49^{\mathrm{E}}$ \\
& 28 & $\mathrm{~S}$ & $4.76 \pm 0.14^{\mathrm{C}}$ \\
& 29 & $\mathrm{~S}$ & $\mathrm{~S}$ \\
Yeast \& mould counts & 1 & $\mathrm{ND}$ & $\mathrm{ND}$ \\
& 7 & $6.10 \pm 0.18^{\mathrm{Aa}}$ & $5.61 \pm 0.11^{\mathrm{aA}}$
\end{tabular}


Nafei et al. (2018). BVMJ-35(2): 134-141

\begin{tabular}{cccc}
14 & $7.80 \pm 0.22^{\mathrm{aB}}$ & $3.41 \pm 0.23^{\mathrm{bB}}$ \\
21 & $\mathrm{~S}$ & $\mathrm{ND}$ \\
28 & $\mathrm{~S}$ & $5.33 \pm 0.06^{\mathrm{C}}$ \\
29 & $\mathrm{~S}$ & $\mathrm{~S}$ \\
Total coliforms \& E. coli counts & 1 & $\mathrm{ND}$ & $\mathrm{ND}$ \\
& 7 & $\mathrm{ND}$ & $\mathrm{ND}$ \\
& 14 & $\mathrm{ND}$ & $\mathrm{ND}$ \\
21 & $\mathrm{~S}$ & $\mathrm{ND}$ \\
28 & $\mathrm{~S}$ & $\mathrm{ND}$ \\
29 & $\mathrm{~S}$ & $\mathrm{~S}$ \\
\hline
\end{tabular}

ND = Non-detected (Non-growth appeared).

S: spoiled sample.

Table 3: Viability of some pathogens in soft cheese coated with 3.53\% EWHs during their refrigerated storage: Staph.aureus, E.coli and Bacillus.subtilus.

\begin{tabular}{|c|c|c|c|}
\hline Microorganisms & $\begin{array}{c}\text { Storage time } \\
\text { (Day) }\end{array}$ & Control sample(log10cfu/g) & $\begin{array}{c}\text { Sample coated with } \\
\text { EWHs }\end{array}$ \\
\hline \multirow{5}{*}{ S. aureus } & Zero & $3.66 \pm 0.025^{\mathrm{aD}}$ & $3.59 \pm 0.018^{\mathrm{aE}}$ \\
\hline & 1 & $3.98 \pm 0.115^{\mathrm{aC}}$ & $3.91 \pm 0.159^{\mathrm{aD}}$ \\
\hline & 3 & $5.48 \pm 0.300^{\mathrm{aB}}$ & $5.15 \pm 0.491^{\mathrm{aC}}$ \\
\hline & 5 & $5.94 \pm 0.722^{\mathrm{aA}}$ & $5.62 \pm 0.932^{\mathrm{aB}}$ \\
\hline & 7 & $4.00 \pm 1.155^{\mathrm{aA}}$ & $6.25 \pm 0.346^{\mathrm{aA}}$ \\
\hline \multirow[t]{5}{*}{ E. coli } & Zero & $4.44 \pm 0.049^{\mathrm{aA}}$ & $4.38 \pm 0.032^{\mathrm{aA}}$ \\
\hline & 1 & $4.12 \pm 0.061^{\mathrm{aB}}$ & $3.08 \pm 0.032^{\mathrm{bB}}$ \\
\hline & 3 & $3.82 \pm 0.393^{\mathrm{aC}}$ & $2.05 \pm 0.014^{\mathrm{bC}}$ \\
\hline & 5 & $2.72 \pm 0.167^{\mathrm{aD}}$ & $1.50 \pm 0.208^{b D}$ \\
\hline & 7 & $2.09 \pm 0.026^{\mathrm{aE}}$ & $1.19 \pm 0.191^{\mathrm{bE}}$ \\
\hline \multirow[t]{5}{*}{ B. subtilus } & Zero & $3.95 \pm 0.061^{\mathrm{aE}}$ & $3.95 \pm 0.028^{\mathrm{aE}}$ \\
\hline & 1 & $5.61 \pm 0.034^{\mathrm{aD}}$ & $5.51 \pm 0.018^{\mathrm{aB}}$ \\
\hline & 3 & $5.72 \pm 0.112^{\mathrm{aC}}$ & $5.01 \pm 0.233^{\mathrm{bC}}$ \\
\hline & 5 & $5.84 \pm 0.489^{a B}$ & $4.52 \pm 0.057^{b D}$ \\
\hline & 7 & $6.78 \pm 0.0449^{\mathrm{aA}}$ & $5.83 \pm 0.292^{\mathrm{bA}}$ \\
\hline
\end{tabular}

$\mathrm{a}, \mathrm{b}$ the differences between the values in the same row are statistically significant ( $\mathrm{p} \leq(\mathrm{P} \leq 0.05)$.

$\mathrm{A}, \mathrm{B}, \mathrm{C}, \mathrm{D}, \mathrm{E}$ the differences between the values in the same column are statistically significant $(\mathrm{P} \leq 0.05)$.

The values were the mean of triplicate \pm standard error (SE). 


\section{DISCUSSION}

\subsection{The antibacterial activity of EWHs against some pathogens in vitro}

The increased use of antibacterial and antifungal agents has resulted in the development of resistance to these drugs. So, the search for discovery of naturally occurring antimicrobial agents has seen rapid growth (Muhle and Tam, 2001). For this reason, EWHs were tested as antimicrobial agents. The power of inhibition of the obtained EWHs was tested against three food pathogenic bacteria including: Bacillus subtilis, Staph. aureus and E. coli, using the agar well diffusion method. The highest antibacterial potency against Bacillus subtilis was shown by the raw hydrolysate obtained at $\mathrm{pH} 1.5$ after $12 \mathrm{hrs}$ (inhibition zone diameter $6.38 \mathrm{~mm}$ ). This might be due to higher activity of pepsin at $\mathrm{pH}$ 1.5 (Adler-Nissen, 1993), and may also due to most major antibacterial EWPs require longer time to be hydrolyzed mainly when present in raw state (Benedé et al., 2014). The variable degrees of antibacterial activity of other hydrolysates against tested strains might be attributed to difference in the protein concentrations of hydrolysates required to achieve the same degree of inhibition (Lorian, 1975).

\subsection{Microbiological profile of soft cheese coated with EWH}

The fungicidal activity of EWHs obtained at pH1.5 may be attributed to many antifungal peptides released from peptic hydrolysis of some antimicrobial egg white proteins mainly lysozyme and ovalbumin which are efficient against Candida albicans (Pellegrini et al., 2004). Also, due to antifungal activity of cystatin peptides against Candida parasitosis and Candida (Kołaczkowska et al., 2010).
4.3. Antibacterial activity of $3.53 \%$ EWHs against some pathogens in soft cheese

The previous data reported that E. coli and Bacillus subtilus were the most sensitive microorganisms to $3.53 \%$ EWHs throughout the refrigerated storage of cheese up to 7 storage days. The antibacterial activity of EWHs against Bacillus subtilus and E. coli in soft cheese increased with increasing refrigerated storage. This may be due to slower transmission of EWHs in food systems (Cagri et al., 2002). However, Staph. aureus is resistant to antibacterial effect of $3.53 \%$ EWHs in cheese samples. The failure of EWHs to inhibit growth of Staph.aureus in soft cheese might be attributed to complex composition of soft cheese that could interfere with the antibacterial activity of $3.53 \%$ EWHs (SmithPalmer et al., 2001).

\section{REFERENCES}

Adler-Nissen, J. (1993): Protease enzymes. In: Enzymes in Food Processing (Reed, G. ed.,), Academic press, San Diego, pp: 159-203.

Aničić, N.V.; Dimitrijević, S.; Ristić, M.; Petrović, S.S. and Petrović S.D. (2005): Peptides with improved antimicrobial activity screened by membrane ultrafiltration from egg white protein hydrolysates. 42nd International Conference of Slovak Society of Chemical Engineering, At Tatranské Matliare, Slovakia, 59: 243-247.

Archer, M. C.; Ragnarsson, J. O.; Tannenbaum, S. R.; and Wang, D. I. (1973):

Enzymatic solubilization of an insoluble substrate, fish protein concentrate process and kinetic considerations. Journal of Biotechnology. Bioeng, 15: 181. 
Benedé, S.; López-Expósito, I.; LópezFandiño, R. and Molina, E. (2014):

Identification of IgE-binding peptides in hen egg ovalbumin digested in vitro with human and simulated gastroduodenal fluids, Journal of Agricultural Food Chemistry, 62: 152-158.

Cagri, A.; Ustunol, Z. and Ryser, E. (2002): Inhibition of three pathogens on

Bologna and Summer Sausage using antimicrobial edible films. Journal of Food Science, 67:2317- 2324.

Crooke, W. M. and Simpson, W. E. (1971): Determination of ammonium in

Kjeldahl digests of crops by an automated procedure. Journal of Agriculture and Food Chemistry 27: 1256-1262.

Dermiki, M.; Ntzimani, A.; Badeka, A.; Savvaidis, I. N.and Kontominas, M. G. (2008): Shelf-life extension and quality attributes of the whey cheese "Myzithra Kalathaki" using modified atmosphere packaging. Laboratory of Food Chemistry and Food Microbiology,41: 284-294.

Deshmukh, D.S.; Zanjad, P.N.; Pawar, V.D. and Machewad, G.M. (2009): Studies on the use of acidified and cultured whey as coagulant in the manufacture of paneer. International Journal of Dairy Technolology, 62(2):174-181.

Egyptian Organization for Standardization and Quality "EOSQ" (2000): Soft

Cheese. Egyptian Organization for standardization and quality control. Part 4: Kareish cheese, ES: 1008-1185.

Garces-Rimon, M.; Gonzalez, C.; Uranga, J. A.; Lopez-Miranda, V.; Lopez-
Fandino, R. and Miguel, M. (2016): Pepsin Egg White Hydrolysate Ameliorates Obesity-Related Oxidative Stress, Inflammation and Steatosis in Zucker Fatty Rats, 11(3):151-193.

Hill, T. and Lewicki, P. (2007): Statistics Methods and Applications. Tulsa, OK. Stat Soft, USA.

Kołaczkowska, A.A.; Sokołowska, H.; Miecznikowska, K. and Rolka, A.P.

(2010): The antifungal properties of chicken egg cystatin against Candida yeast isolates showing different levels of azole resistance. Journal of mycoses, 53: 314-320.

Lahi, W.J. and Braun, S.D. (1994): Enzymatic production of protein hydrolysates for food use. Journal of Food Technology, 48:68-71.

Lorian, V. (1975): Some effects of subinhibitory concentrations of antibiotics on bacteria. Bulletin of the New York Academy of Medicine, 51:1046-1055.

Miguel, M.; Manso, M.A.; Lopez-Fandino, R. and Ramos, M. (2005):

Comparative study of egg white proteins from different species by chromatographic and electrophoretic methods. European Food Resource Technology Journal, 221:542-546.

Mine, Y. and Kovacs-Nolan, J. (2006): Biologically active hen egg components in human health and disease. Journal of Poultry Science, 41:1-29.

Mucchetti, G.C.; Remagni, M.; Ghiglietti, R.; Locci, F.; Barzaghi, S.; Francolino, S.; Perrone, A.; Rubiloni, A.; Campo, P.; Gatti, M and Carminati, D. (2008): Influence of cheese-making technology 
on composition and microbiological characteristics of Vastedda cheese. Food Control Journal, 19: 119-125.

Muhle, S.A. and Tam, J.P. (2001): Design of Gram-negative selective antimicrobial peptides, Biochemistry Journal, 40:5777-5785.

Pedersen, P. (1994): Removing bitterness from protein hydrolysates. Food Technology Journal, 48: 96-98.

Pellegrini, A.; Hulsmeier, A. J.; Hunziker, P. and Thomas, U. (2004): Proteolytic fragments of ovalbumin display antimicrobial activity. Biochemical et Biophysical Acta, 1672: 76-85.

Sadek, I.; Hosny, I.M.; El Kholy, W.I. and El Dairouty, R.K. (2009): Comparative

Investigations for detection of food borne microorganisms in Egyptian cheese using conventional and fast biochemical tests. Global Veterinaria Journal, 3:189195.

Smith-Palmer, A.P.; Stewart, J. and Fyfe, L. (2001): The potential application of

Plant essential oils as natural food preservatives in soft cheese. Journal Food Microbiology, 18: 463-470.

Tian, B. O. (2001): Preparation of the hydrolysate of protein in egg white. Harbin: Northeast Agricultural University 58(2):143-146.

Van dijk, A.; Veldhuizen, E. J.; and Haagsman, H. P. (2008): Avian defensins. Veterinary Immunology and Immunopathology Journal, 124: 1-18.

Wong, J.H. and Ng, T.B. (2005): Lunatusin, a trypsin-stable antimicrobial peptide from Lima beans (Phaseolus lunatus L.). Peptides, 26: 2086-2092. 